\title{
Assessment of cassava supply response in Nigeria using vector error correction model (VECM)
}

\author{
Oluwakemi Adeola OBAYELU*, Samuel EBUTE \\ University of Ibadan, Faculty of Agriculture and Forestry, Ibadan, Nigeria
}

\begin{abstract}
The response of agricultural commodities to changes in price is an important factor in the success of any reform programme in agricultural sector of Nigeria. The producers of traditional agricultural commodities, such as cassava, face the world market directly. Consequently, the producer price of cassava has become unstable, which is a disincentive for both its production and trade. This study investigated cassava supply response to changes in price. Data collected from FAOSTAT from 1966 to 2010 were analysed using Vector Error Correction Model (VECM) approach. The results of the VECM for the estimation of short run adjustment of the variables toward their long run relationship showed a linear deterministic trend in the data and that Area cultivated and own prices jointly explained $74 \%$ and $63 \%$ of the variation in the Nigeria cassava output in the short run and long-run respectively. Cassava prices $(\mathrm{P}<0.001)$ and land cultivated $(\mathrm{P}<0.1)$ had positive influence on cassava supply in the short-run. The short-run price elasticity was 0.38 indicating that price policies were effective in the short-run promotion of cassava production in Nigeria. However, in the long-run elasticity cassava was not responsive to price incentives significantly. This suggests that price policies are not effective in the long-run promotion of cassava production in the country owing to instability in governance and government policies.
\end{abstract}

Key words: price, co-integration, trend analysis, change in cassava supply

\section{INTRODUCTION}

Cassava (Manihot esculenta Crantz) is a staple food crop cultivated in several developing tropical countries. Cassava is consumed either directly as cooked tubers or indirectly as processed products. In sub-Saharan Africa, cassava output grew from 48.34 million tonnes in 1980 to 140.97 million tonnes in 2011 with a growth in productivity from 6.85 tonnes/ha to $10.8 \mathrm{t} /$ ha during the same period (FAO, 2013). It is grown in 102 countries in the world. African continent occupies the first position covering $66.21 \%$ of area planted with cassava and $53.37 \%$ of the world cassava production. Although its production area is more in Africa, its output is low due to low productivity (8.824 tonnes/ha) which is lower than the world average productivity. (Srinivas, 2005). Nigeria has the largest area under cassava (22.25\%) among all the cassava growing countries in the world with an annual output of 40 million tonnes in 2011 (NBS, 2011). Supply of cassava greatly influences the market price. When cassava is scarce and its prices are high, farmers increase production. The subsequent excess supply in the next production cycle lowers the market price and farmers plant less cassava in the subsequent production period. This results in fluctuating price cycles of approximately two to three years (EkeOkoro, 2004). Cassava farmers are often unable to process harvested tubers and have to sell their crop at a very low price to middlemen who are willing and able to reach them. In recent years the economic performances of rural agricultural enterprises in Nigeria has suffered from declining prices for cassava and other key commodities. Evidence has shown that cassava production has been increasing fairly since 1999, however, substantial losses from post-harvest systems such as processing, packaging, marketing, storage distribution and transportation have constrained income from the production of this crop (RUSEP 2002; FMARD 2004).

Self-food-sufficiency is a crucial political-economic goal of the Nigerian government (Bello, 2004) and it has been a major debate among economist and policy makers. 
Policy regimes have included those focusing on economic diversification, national self-reliance, structural adjustment, economic consolidation and expansion and national food security. (Vision 2010 Committee, 1997 as cited by Awosola et.al, 2006). The ability of the agricultural policy community to respond to this challenge is impaired by lack of basic information about agricultural sector. Information on current market prices is relatively scarce and projections of future prices are difficult. Similarly, basic economic information concerning the supply of agricultural production is missing. Agricultural supply response is closely associated with the change in agricultural output owing to a change in agricultural output price (Mythili, 2008) and this may be policy-induced and was found to be responsive to price incentives in Nigeria (Obayelu and Salau, 2010). Today the producers of traditional agricultural commodities in Nigeria face the world market directly. They reap profits when prices are good but absorb shocks and suffer losses when prices fall. Consequently, the producer's price of these commodities has become unstable and this create dis-incentive for production thus making output and exports to suffer (Mesike et al., 2008). This could have negative implications for the agricultural industry and the national income.

In agricultural development economics, the most important issue is supply response since the responsiveness of farmers to economic incentives largely determines agriculture's contribution to the economy. The response of agricultural supply to price movements has been the subject of long and vigorous discussion, going back to Nerlove's classic treatment of the long-run supply elasticity for corn, cotton and wheat in the United States (Nerlove 1958). Estimates of supply elasticity (short-run and long-run) based on the Nerlove model vary widely depending on crop and region. Furthermore, the response elasticities are also important for policy decision regarding agricultural growth. Therefore considering of these limitations, the current study utilizes the new developments of econometric techniques in analysis that can estimate distinct short-run and long run elasticities to overcome the problem usually encountered in the traditional Nerlovian model. However, the Error Correction Model (ECM) with co-integration analysis is preferred to the Nerlovian model because it not only overcomes the restrictive dynamic specification of the Nerlove method, but also captures the forward-looking behaviour of producers optimising their production in dynamic situations. ECM is used to analyse non-stationary time series that are known to be co-integrated.

The measurement of agricultural supply response prove not only useful to policy makers, but also facilitates informed decision making by farmers and other players in the production marketing chain and ultimately results in better prices for the consumers. The responsiveness of farmers to price and non-price incentive or disincentives will provide a clear picture of contribution of agricultural sector to the economy and this will depend often on the responsiveness of domestic agricultural production to price in particular. Therefore, any meaningful attempt to reform the structure of incentives provided by cassava farmers will require a detailed knowledge of cassava supply parameters. Hence, the use of VECM approach to investigate the response of cassava output supply to the real prices with a lapse of time. This study therefore analyses cassava farmers' responsiveness on the price from the period of 1966 (when the first military coup took place) to 2010 .

\section{MATERIALS AND METHODS}

The study sourced data from Food and Agricultural Organization of the United Nation (FAO), Central Bank of Nigeria (CBN) and National Bureau of Statistics (NBS). The variables chosen include cassava output, area, real prices of cassava, land area cultivated. Raw cassava price data from 1966 to 2010 were deflated using 2012 consumer price index. Each of the series was then tested for the presence of a unit root by estimating an Augmented Dickey Fuller (ADF) equation. The first lagged difference of all non-stationary series and again estimated ADF equation both with and without the deterministic trend.

The cointegration and the Vector Error Correction Model (VECM) were estimated using the Johansen (1988) test which estimates Vector Error Correction Models (VECM) of the form:

$$
\begin{gathered}
\Delta Y_{t}=c+\sum_{j} \alpha_{j} \Delta Y_{t-1}+\delta D_{t}+\gamma T+\lambda \varepsilon_{t-1}+\vartheta_{t} \\
\varepsilon_{t-1}=\ln Y_{t-1}-\sum_{j} \beta_{j} Y_{j t-1}(\text { error/equilibrium correction term })
\end{gathered}
$$

Where where $\Delta$ is the deference operator such that $\Delta Y_{t}=Y_{t}-Y_{t-1}$, Ys are the (assumed) co-integrated time series variables (including pervious supply levels $Y_{t-n}$ and explanatory variables $\left.X_{t-n}\right) . \mathrm{D}_{\mathrm{t}}$ is a vector of stationary exogenous variables; $\delta$ is vector of parameters of exogenous variables; $\lambda$ is the coefficient of error correction term $\varepsilon_{t-1}$. aj and $\beta j$ are respectively vectors of short-run and long-run supply elasticities with respect to factor $j$.

The Johansen method provides two likelihood ratio tests, namely the Trace and the Maximum Eigen Value statistic tests, which are used to determine the number of co-integrating equations given by the co-integration rank r. A co-integration equation is the long-run equation of cointegrated series. The Trace statistic tests the null hypothesis of $\mathrm{r}$ co-integrating relations against the alternative of $\mathrm{k}$ cointegrating relations, where $\mathrm{k}$ is the number of endogenous variables for $\mathrm{r}=0,1, \ldots, \mathrm{k}-1$. The Maximum Eigen Value statistic tests the null hypothesis of $\mathrm{r}$ co-integrating vectors against the alternative of $r+1$ cointegrating vectors.

When the co-integration rank $r$ is equal to 1 , the normalisation restriction for the parameters produces a unique estimate of what the economic theory suggests (Golinelli, 2003). However, when there is more than one cointegration equation the Johansen approach to co-integration analysis is preferred to the Engle-Granger approach (Thiele, 2003).

The VECM was specified as:

$\Delta \ln \mathrm{Y}_{\mathrm{t}}=\mathrm{c}+\mathrm{a}_{\mathrm{o}} \Delta \ln \mathrm{P}_{\mathrm{t}-1}+\alpha_{1} \Delta \ln \mathrm{k}_{\mathrm{t}-1}+\alpha_{2} \Delta \ln \mathrm{C}_{\mathrm{t}-1}+\gamma \mathrm{T}+\lambda \varepsilon_{\mathrm{t}-1}+9 \mathrm{t}$ 
For this study:

$\Delta \ln \mathrm{Y}_{\mathrm{t}-1}=\mathrm{C}+\mathrm{a}_{\mathrm{o}} \ln \mathrm{P}_{\mathrm{t}-1}+\mathrm{a}_{1} \ln \mathrm{A}_{\mathrm{t}-1}+\varepsilon_{\mathrm{t}-1}$

Where:

$\mathrm{Y}_{\mathrm{t}-1}=$ lagged output

$\mathrm{P}_{\mathrm{t}-1}=$ lagged price of cassava

$\mathrm{A}_{\mathrm{t}-1}=$ lagged area of land cultivated

$\mathrm{C}=$ constant term

$\varepsilon_{\mathrm{t}-1}=$ lagged error term

\section{RESULTS AND DISCUSSION}

\section{Trend analysis of cassava production and price}

The trend analysis in Figure 1 shows that between the periods of 1966-1985, popularly known as the pre-Structural Adjustment Program (SAP) era, cassava production was at best described as stagnant as there was no real growth in the sector. This was the outcome of the oil boom of the 1970s, which later led to the "Dutch syndrome". In the late 1980s, the military regime international financial institutions supported the introduction of Structural Adjustment Programme (SAP) in Nigeria to correct market and price distortions. The SAP was a policy measure towards a more market-friendly trading system and the dissolution of commodity marketing boards as well as elimination of the heavy dependence on crude oil export and import of consumer and producer good
(Ihimodu, 1993). During the SAP era, cassava output grew steadily from about 10 million tonnes (MT) in 1985 to $30 \mathrm{MT}$ 1994. Thereafter, it took a downward trend but for the timely intervention of the Presidential Cassava Initiative under the Obasanjo regime from 1999 to 2007 and peaked in 2006 to about 49 MT.

Efforts of the Obasanjo regime to diversify the Nigerian economy from an oil-based economy led to growth in the agricultural sector including the exponential expansion of cassava production from 2003 to 2007. However, the glut created in the market, which coincided with a change in government and government policy focus, led to a sharp decline in cassava output to about 35 MT in 2008. The seven-point agenda of the Yaradua government included agricultural sector development but were later actualised by Goodluck Jonathan regime. Local content policies, such as the popular cassava flour inclusion in the milling industry and bilateral agreements with multinationals in the textile and the pharmaceutical industries, resulted in the upward trend of cassava output in 2010.

\section{Trend analysis of raw cassava prices}

The agricultural production like any other around the world responds not only to non-price factors such as policies and weather but also to price incentives. Figure 2 shows that cassava prices were low and relatively stable during the preSAP period (1966-1985) but a sharp change was observed in the price movement, which corresponded with exponential increase in production output immediately after the introduction of SAP. The sharp decline in the price of cassava

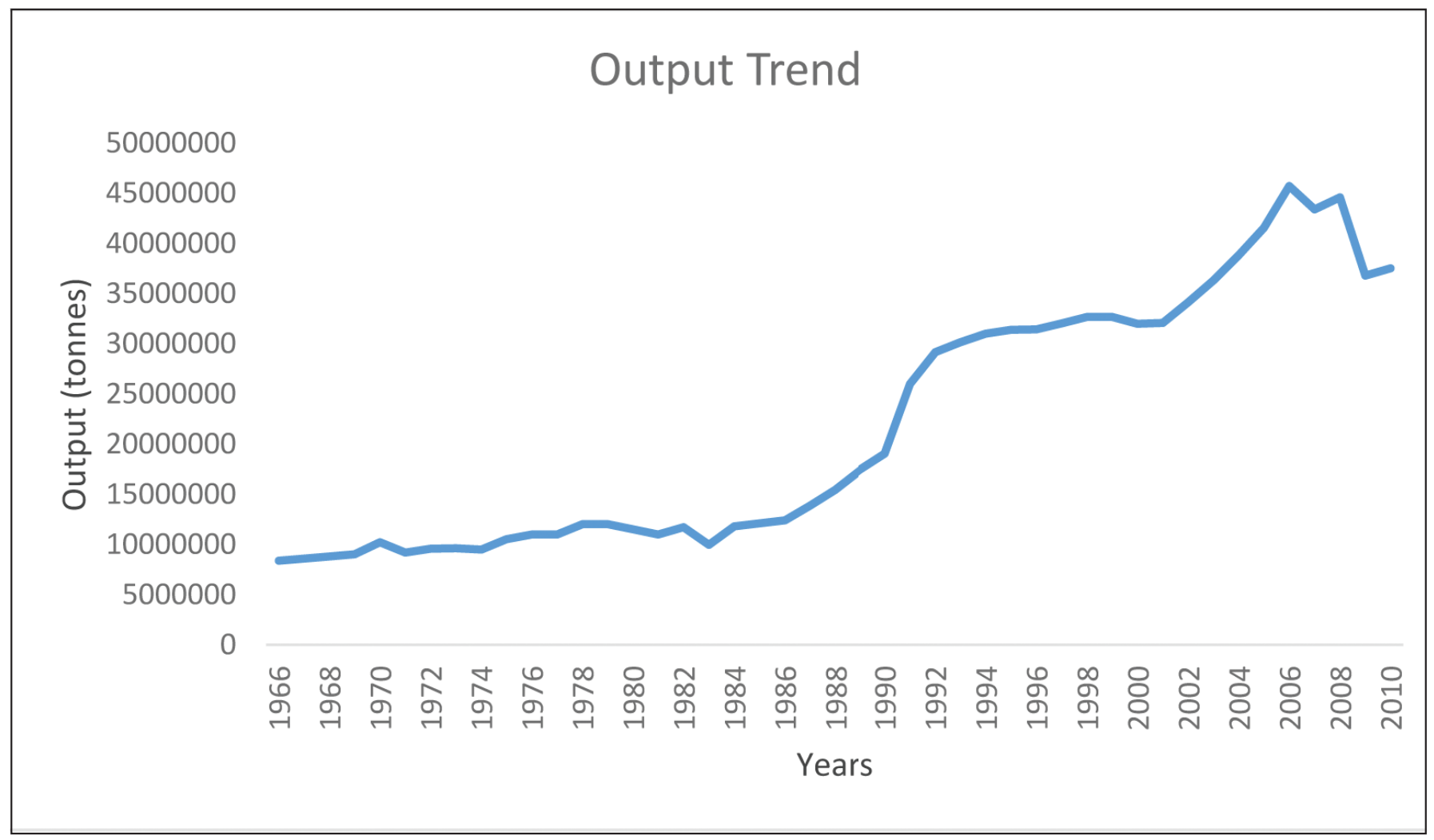

Fig. 1: Trend analysis of cassava production in Nigeria 


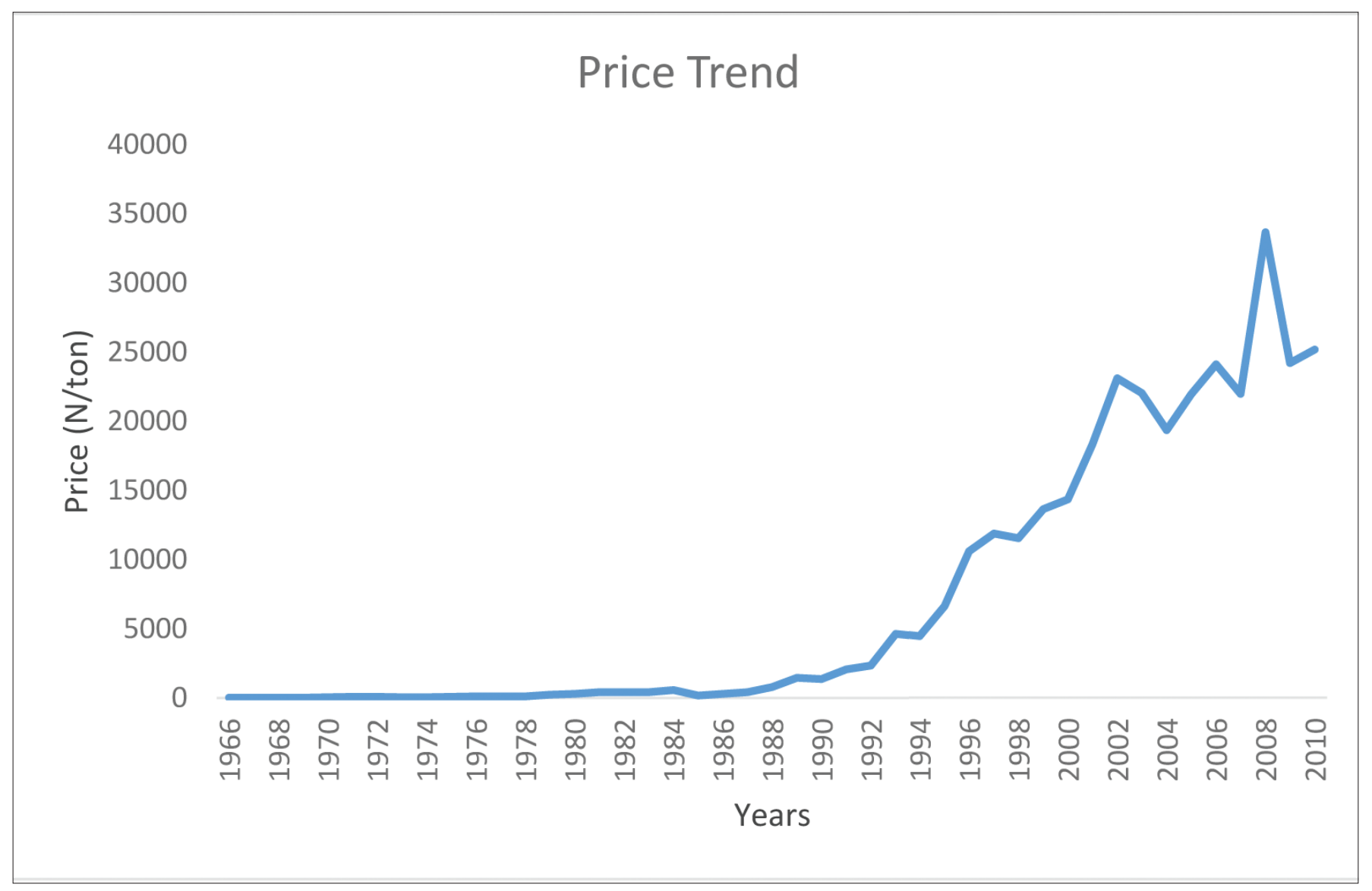

Fig. 2: Trend analysis of cassava prices in Nigeria

around 2008 can be attributed to the glut in the market at the period. From then onwards, there was an undulating increase in the trend of cassava price.

\section{Stationarity test}

The unit root test using the Augmented Dickey Fuller (ADF) presented in Table 1 showed that all the variables were non-stationary in their levels but were stationary at first differences. The test used the MacKinnon (1991) critical values for the rejection of the null hypothesis of no unit root. This indicated that the variables were I(1) and any attempt to specify the dynamic function of the variable in the level of the series will be inappropriate and may lead to spurious results in the long-run analysis (Mesike et al., 2010). Therefore, the test of co-integration was applied to the series data which were integrated in the same order I(1) but did not have a unit root.

\section{Co-integration test}

The Johansen's co-integration test showed the presence of three co-integrating equations at $5 \%$ level of significance implying a common trend in the process (Table 2). The co-

Table 1: Augmented Dickey Fuller (ADF) stationarity test

\begin{tabular}{|l|l|l|l|l|l|}
\hline \multicolumn{9}{|l|}{ ADF Test Critical Values } \\
\hline Variables & Statistics & $1 \%$ & $5 \%$ & $10 \%$ & Inference \\
\hline $\mathrm{D}(\mathrm{Y})$ & 0.5469 & -3.6056 & -2.9369 & -2.6069 & $\mathrm{I}(0)$ \\
\hline & -3.6416 & -3.6105 & -2.9390 & -2.6080 & $\mathrm{I}(1)$ \\
\hline $\mathrm{D}(\mathrm{A})$ & -1.6330 & -4.9809 & -3.5155 & -3.1883 & $\mathrm{I}(0)$ \\
\hline & -5.8244 & -4.1865 & -3.5181 & -3.1897 & $\mathrm{I}(1)$ \\
\hline $\mathrm{D}(\mathrm{P})$ & -1.0804 & -4.1985 & -3.5236 & -3.1929 & $\mathrm{I}(0)$ \\
\hline & -4.7951 & -4.2050 & -3.5266 & -3.1946 & $\mathrm{I}(1)$ \\
\hline
\end{tabular}

ADF : Augmented Dickey Fuller; I(0) : non-stationary at level;

$\mathrm{I}(1)$ = stationary at first difference; $\mathrm{D}(\mathrm{Y})=$ output of cassava; $\mathrm{D}(\mathrm{A})=$ production area; $\mathrm{D}(\mathrm{P})=$ price of cassava; 
Table 2: Summary of co-integration test

\begin{tabular}{|l|l|l|l|l|l|}
\hline $\begin{array}{l}\text { Hypothesised No. } \\
\text { of CE }\end{array}$ & Null Hypothesis & Alt. Hypothesis & Eigen Value & Trace Stat. & $\begin{array}{l}5 \% \text { Critical } \\
\text { value }\end{array}$ \\
\hline None & $\mathrm{r}=0$ & $\mathrm{r}=1$ & 0.6611 & 92.6800 & $69.8188^{*}$ \\
\hline Atmost 1 & $\mathrm{r}<1$ & $\mathrm{r}=2$ & 0.5199 & 55.8934 & $47.8561^{\star}$ \\
\hline Atmost 2 & $\mathrm{r}<2$ & $\mathrm{r}=3$ & 0.4202 & 30.9472 & $29.7971^{\star *}$ \\
\hline Atmost 3 & $\mathrm{r}<3$ & $\mathrm{r}=4$ & 0.2974 & 12.4147 & 15.4949 \\
\hline Atmost 4 & $\mathrm{r}<4$ & $\mathrm{r}=5$ & 0.0122 & 0.4157 & 3.8415 \\
\hline
\end{tabular}

$\mathrm{Hp}:$ rank $=\mathrm{p}$ (no deterministic trend in data) $\mathrm{Hr}$ : rank $\mathrm{r}<\mathrm{p}$ Co integration relations.

${ }^{* *}\left({ }^{*}\right)$ denotes rejection of hypothesis at $5 \%(1 \%)$ significant levels. Test indicates 3 cointegrating equations(CE) at $5 \%$.

integration tests were to test whether there was a statistical significant linear relationship between the different timeseries data. Test statistics from the maximum Eigen value are consistent in suggesting that there are two integrating vectors among the variables. This suggested that the explanatory variables were co-integrated and had both short run and long run relationships with the dependent variable.

The statistical evidence of co-integration supports the theory of long-run equilibrium between supply and output. It also supports three co-integration relation between the series and hence the decision regarding co-integration equation. The results, based on both the trace test and maximum Eigen value test showed the existence of three co-integrating vectors and the rejection of the null hypothesis of $r=0$. Thus, there is a long-run co-integrating relationship among the variables. This is consistent with the findings of Hallam and Zanoli (1992) as cited in Obayelu and Salau (2010) that where only one co-integrating equation exists, its parameters can be interpreted as estimates of long-run co-integrating relationship between the variables concerned.

\section{Vector error correction estimates}

Lagged variables were used in the estimation of cassava output, as the production decisions of the famers are mostly made in the previous period and they are not altered on real time basis due to change in any of the variables. The result showed that the independent variables jointly explained $74.01 \%$ of the variations in the cassava supply in the shortrun. The elasticity of current production with respect to previous production was $37.7 \%$. Most parameter estimates were within reasonable ranges suggesting a relatively strong short-run supply response to prices, meaning an increase in aggregate cassava output in the short-run will lead to a decrease in the price of cassava (Obayelu and Salau, 2010). The estimated speed of adjustment was significant at one percent and this reveal that cassava supply adjusts to correct for short-run disequilibrium between itself and its price. The error correction coefficient was very high (98\%) and had a negative sign, implying that feedback mechanism is high in converging cassava supply towards long run equilibrium despite the shocks in cassava supply and prices.

Production decisions are mostly made in the previous year and they are not subject to alterations on real time basis due to change in any of the variables (Ozkan, 2011). Thus, considering the annual structure of the cassava production, the amount of production in the previous year is correlated with the current production. The negative sign on the lagged cassava output suggested that given the existence of a market glut in the previous period, cassava could be replaced with its substitutes such as yam and sweet potatoes. In other words, an increase in cassava supply resulting in a decline its price will make the famers shift cassava production to its close substitutes like yam, thereby reducing its output supply. This makes them eligible for this substitution in the long-run. The opportunity to utilize substitutes is a key proviso that is attributable to the negative constant of the estimation. The cassava price elasticity and the elasticity of farm size in the short-run were 0.38 and 0.27 respectively suggesting that a percentage increase in both the lagged price of cassava and farm size price led to a less than proportionate percentage increase in aggregate cassava supply in the short-run. This indicated that cassava supply was price inelastic in the shortrun. Also, cassava farmers in Nigeria did not make adequate short-run production expansion adjustments in response to changes in expected prices. This may be due to relative price stability overtime and non-price determinants of supply response.

In the long-run, all the explanatory variables jointly explained 63 percent of the variations in cassava output. The coefficient of the error term is significant and greater than unity in the long-run and is consistent with the findings of Obayelu and Salau (2010), implying a high speed of adjustment towards equilibrium. In other words, the speed at which cassava output adjusted to the explanatory variables in the long-run was $100.5 \%$, which was a marginal increase from $98 \%$ in the short-run. However, lagged cassava price was not significant in the long-run suggesting that price policies were not effective in the long-run promotion of cassava production in the country owing to instability in governance and government policies. This is consistent with the findings of Ozkan et al., 2013 that current production did not respond significantly to the lagged own price of wheat in the long-run in Turkey. However, it contradicted the findings of Ogundari and Nanseki (2013) that maize supply responded significantly and positively in the long run to own price in Nigeria. 
Table 3: Short-run vector error correction estimates.

\begin{tabular}{|l|l|l|l|}
\hline Variables & Co-efficient & St. Error & t. value \\
\hline C & -270459.2 & 238197.5 & -1.135441 \\
\hline $\mathrm{D}(\mathrm{Y}-1)$ & $-0.377316^{* * *}$ & 0.118843 & -3.174918 \\
\hline $\mathrm{D}(\mathrm{A}-1)$ & $0.2749004^{\star}$ & 0.141884 & 1.937497 \\
\hline $\mathrm{D}(\mathrm{P}-1)$ & $0.382407^{\star * *}$ & 0.104133 & 3.672281 \\
\hline E-1 & $-0.980299^{* * *}$ & 0.148231 & 6.613324 \\
\hline R. Squared. & 0.740103 & & \\
\hline Adj. R. Square & 0.704255 & & \\
\hline S.E. Equation & 1.388426 & & \\
\hline $\begin{array}{l}\text { Sum of Sq. } \\
\text { res. }\end{array}$ & $5.59 \mathrm{E}+13$ & & \\
\hline $\begin{array}{l}\text { Log } \\
\text { likelihood }\end{array}$ & -526.4250 & & \\
\hline F. Statistics & 20.64568 & & \\
\hline $\begin{array}{l}\text { Mean dep. } \\
\text { Var. }\end{array}$ & -258167.6 & & \\
\hline S.D Var. & 2553079 & & \\
\hline $\begin{array}{l}\text { Akaike Info. } \\
\text { C. }\end{array}$ & 31.26029 & & \\
\hline Shwarz C. & 31.48476 & & \\
\hline DubinWat. St. & 1.014693 & & \\
\hline
\end{tabular}

$\left({ }^{* *}\right) *$ Significant at $(1 \%)$ and $10 \%$ respectively

Table 4: Long-run vector error correction estimates.

\begin{tabular}{|l|l|l|l|}
\hline Variables & Co-efficient & $\begin{array}{l}\text { Standard } \\
\text { Error }\end{array}$ & t-value \\
\hline C & $767457.7^{* * *}$ & 249459.7 & 3.076480 \\
\hline Y-1 & -0.03460 & 0.172640 & 0.200535 \\
\hline A-1 & 0.733647 & 1.721046 & 0.426280 \\
\hline P-1 & 0.2182142 & 2.083508 & 0.104734 \\
\hline E-1 & $1.005688^{* * *}$ & 0.156314 & 6.433782 \\
\hline R. Squared. & 0.637226 & & \\
\hline Adj. R. Square & 0.587188 & & \\
\hline S.E. Equation & 1452898 & & \\
\hline $\begin{array}{l}\text { Sum of Sq. } \\
\text { res. }\end{array}$ & $6.12 \mathrm{E}+13$ & & \\
\hline $\begin{array}{l}\text { Log } \\
\text { likelihood }\end{array}$ & -527.9682 & & \\
\hline F. Statistics & 12.73488 & & \\
\hline $\begin{array}{l}\text { Mean dep. } \\
\text { Var. }\end{array}$ & 773655.9 & & \\
\hline S.D Var. & 2261304 & & \\
\hline $\begin{array}{l}\text { Akaike Info. } \\
\text { C. }\end{array}$ & 31.55107 & & \\
\hline Shwarz C. & 31.42762 & & \\
\hline DubinWat. St. & 1.060433 & & \\
\hline$* * \star$ sifant & $1 \%$ & \\
\hline
\end{tabular}

$(* *)$ significant at $1 \%$.

\section{CONCLUSION AND RECOMMENDATIONS}

This study examines the supply response of cassava using vector error correction analysis which incorporates both a more general dynamic structure than Nerlovian models and overcomes the potential problem of spurious regression. The result of the trend analysis showed that cassava development and In addition to the acreage allocation response that agricultural producers make towards price changes, they also react to expected changes in terms of yield response. production output have risen over the years in Nigeria in the recent past and that price played a significant role in production decisions. While yield responses to own output prices are positive, the response towards output price volatilities is modest. Thus, besides via acreage changes, the global food supply response to expected prices comes from yield changes. Results showed that cassava output supply response in Nigeria largely depended on its own price and land area in the short-run. The estimated short-run and long run elasticities indicated that the cassava supply response to price was inelastic.

The area elasticity coefficient from the short run analysis suggested increase in the area cultivated will lead to an increase in cassava output, efforts should therefore be put in place by government and extension agents to increase the area cultivated and improve the yield potentials in terms of productivity of the fields thereby maximising output. Further, cassava has high price elasticity in the short-run. Policies should be put in place that stabilises the price of cassava in the market.

\section{REFERENCES}

1. Bello A. Nigeria Imported \$US700 million rice in 2003: Federal Minister of Agriculture and Rural Development -Mallam Adamu Bello in Nigerian Tribune Newspaper. Monday 7th July, [2004].

2. Eke-Okoro, CN. Optimum rate of new compound fertilizer for cassava production in south eastern Nigeria. Journal of Research in Agriculture 2004; 4 (1): 23-26.

3. Food and Agricultural Organisation FAOSTAT statistical data base 2013. (http://faostat.fao.org).

4. Federal Ministry of Agriculture and Rural Development (FMARD) (2004). Ministerial press briefing by Minister of Agriculture and Rural Development on the state of Nigerian Agriculture at Maizube Farms, Niger State, May 16, 2004,

5. Granger CWJ. Developments in the study of cointegrated economic variables. Oxford Bulletin of Economics and Statistics 1986; 48:213-228.

6. Hallam D, Zanoli R. Error correction models and agricultural supply response. Eur Rev Agric Econ, 1992; 2:111-120.

7. Johansen S, Juselius K. Maximum likelihood estimation and inference on cointegration - with Applications to the demand for money. Oxford Bulletin of Economics and Statistics 1990; 52, 169-210. 
8. McKay A, Morrisey O, Vaillant C. Aggregate supply response in Tanzanian agriculture. The Journal of International Trade and Economic Development 1999; 8(1): 107-23.

9. Mesike CS, Okoh RN, Inoni OE. Supply response of rubber farmers in Nigeria: An application of Vector Error Correction Model. Agricultural Journal 2010; 5:146-150.

10. Mythili G. Acreage and yield response for major crops in the pre-and post-reform periods in India: A dynamic panel data approach. PP Series 061, Indira Gandhi Institute of Development of Research, Mumbai. 2008

11. Nerlove M. The dynamics of supply: estimation of farmers' response to price. Johns Hopkins, Baltimore. 1-23. 1958.

12. Obayelu AE, Salau AS. Agricultural response to prices and exchange rate in Nigeria: Application of Co-integration and Vector Error Correction Model. J. Agri Sci. 2010; (2):73-81 (2010).

13. Ogazi CG. Rice output supply response to the changes in real prices in Nigeria: An Autoregressive Distributed Lag Model Approach. Journal of Sustainable Development in Africa 2009;11(4):83-100. Clarion University of Pennsylvania, Clarion, and Pennsylvania.

14. Ogundari K, Nanseki T. Maize supply response to prices in Nigeria: Application of ARDL and co-integration analyses. Dept. of Agricultural and Resource Economics, Faculty of Agriculture, Kyushu University, Fukuoka, Japan. 2013.

15. Ojiako IA, Manyong VM, Ikpi AE. Smallholder soybean farmers' supply response in Northern Nigeria. Journal of Agricultural and Food Economics, 2008;3(1-2): 4353.

16. Onono PA, Wawire NWH, Ombuki C. The response of maize production in Kenya to economic incentives. International Journal of Development and Sustainability 2013; 2(2)P: 530-543.

17. Ozkan B,. Ceylan RF, Kizilay H. Supply response for wheat in Turkey: a vector error correction approach. NEW MEDIT N. 3/2011,

18. Thiele R. Price incentives, non-price factors and agricultural production in sub-Saharan Africa: A co-integration analysis. Paper presented at the 25th International Conference of Agricultural Economists, Durban, South Africa, p 16. 16-22 August 2003. 


\section{Ocena odziva ponudbe/oskrbe s kasavo v Nigeriji $\mathrm{z}$ uporabo modela za vektorsko popravljanje napak (VECM)}

\section{IZVLEČEK}

Odziv kmetijske proizvodnje na spremembe cen je pomemben dejavnik pri uspehu kateregakoli programa reform $\mathrm{v}$ kmetijskem sektorju v Nigeriji. Proizvajalci tradicionalnih kmetijskih proizvodov, kot je na primer kasava, se neposredno soočajo s svetovnim trgom. Posledica je nestabilna cena kasave, kar neugodno vpliva na pridelavo in trženje/prodajo kasave. Cilj raziskave je bil preučiti odziv ponudbe/oskrbe s kasavo na spremembe v ceni. Podatki, zbrani iz baze FAOSTAT za obdobje 1966 do 2010, so bili analizirali z modelom za vektorsko popravljanje napak (VECM). Rezultati analize VECM za oceno kratkoročne prilagoditve spremenljivk v smeri njihove dolgoročne povezanosti/razmerja so pokazali linearno deterministični trend $\mathrm{v}$ podatkih ter da obdelane površine in lastna cena skupaj kratkoročno in dolgoročno razložita $74 \%$ in $63 \%$ variabilnosti proizvodnje kasave v Nigeriji. Cene kasave $(\mathrm{P}<0,001)$ in obdelana zemljišča $(\mathrm{P}<0,1)$ imajo pozitiven vpliv na kratkoročno oskrbo s kasavo. Kratkoročna elastičnost cene je bila 0,38, kar kaže na to, da je bila cenovna politika učinkovita pri kratkoročnem spodbujanju proizvodnje kasave v Nigeriji. Po drugi strani pa pri dolgoročni elastičnosti ni bila ugotovljena značilna odzivnost kasave na cenovne spodbude. Na osnovi rezultatov domnevamo, da cenovna politika ni učinkovita pri dolgoročnem vzpodbujanju pridelave kasave v državi zaradi nestabilnosti vlade in vladne politike.

Ključne besede: cena, kointegracija, analiza trenda, spremembe v oskrbi s kasavo 